\title{
EPIDEMIOLOGY OF VENEREAL DISEASE IN PORTUGAL DURING THE SECOND WORLD WAR, 1939-45*
}

\author{
BY \\ F. NORTON BRANDAÕ \\ Central Dispensary of Social Hygiene, Lisbon
}

(Director: Dr. C. Nina)

Although Portugal was a neutral country many social and economic changes were brought about by the war. Thousands of refugees congregated in or near large towns and there was much movement of troops, especially to the off-shore islands and overseas territories. All these circumstances created conditions favourable to the spread of venereal disease.

It is not proposed to analyse in detail the social factors which are known to favour the increase of these diseases, but to examine the influence of the migration of certain population groups on the incidence of venereal disease.

The records of the chief dermato-venereological centre in Portugal, the Desterro Hospital, show a remarkable increase in venereal disease between 1939 and 1945 (see Table and Figure, opposite).

Gonorrhoea is not included because this condition is treated in the urological department, but this too showed a large increase.

Disregarding socio-economic considerations, one of the factors which contributed greatly to this increase, was the movement of large bodies of troops to stations overseas. The arrival of military forces in any part of the world immediately leads to much clandestine prostitution. This is difficult to control from the public health aspect, especially when it first begins, and it therefore becomes an important source of infection. On the other hand, just before embarkation, men who are usually continent in their habits display intense sexual activity and often become infected. By the time they reach their destination the disease is fully developed. It may also happen that venereal diseases are already rife among the natives, as for example in the Cape Verde

*Paper read at General Assembly of I.U.V.D.T., London, October 161959. islands, where primary syphilis, gonorrhoea, and chancroid were fairly common.

The situation has now been brought under control

TABLE

CASES OF VENEREAL DISEASES AT THE DESTERRO HOSPITAL, LISBON, 1932-55

\begin{tabular}{|c|c|c|c|c|c|}
\hline & Year & & $\begin{array}{l}\text { Contagious } \\
\text { Syphilis }\end{array}$ & $\begin{array}{c}\text { Soft } \\
\text { Chancre }\end{array}$ & $\begin{array}{l}\text { Lymphogranuloma } \\
\text { Venereum }\end{array}$ \\
\hline 1932 & . & $\ldots$ & 99 & 14 & 1 \\
\hline 1933 &. & . & 82 & 8 & 8 \\
\hline 1934 & . & . & 486 & 414 & 29 \\
\hline$\overline{1935}$ & $\ldots$ & $\ldots$ & 404 & 589 & 15 \\
\hline 1936 & . & $\ldots$ & 494 & 494 & 34 \\
\hline 1937 & $\ldots$ & $\ldots$ & 424 & 337 & 45 \\
\hline 1938 & . & . & 520 & 379 & 45 \\
\hline 1939 & . & . & 427 & 1,117 & 52 \\
\hline 1940 & $\ldots$ & $\ldots$ & 537 & 725 & 84 \\
\hline 1941 &. &. & 657 & 365 & 133 \\
\hline 1942 & . & . & 672 & 969 & 96 \\
\hline$\overline{1943}$ & $\ldots$ & $\ldots$ & 638 & 760 & 212 \\
\hline 1944 &. & $\cdots$ & 534 & 795 & 157 \\
\hline 1945 & . & . & 597 & 736 & 283 \\
\hline 1946 &. & $\ldots$ & 576 & 1,152 & 234 \\
\hline 1947 & $\ldots$ & . & 693 & 312 & 221 \\
\hline 1948 & $\ldots$ & $\ldots$ & 334 & 376 & 177 \\
\hline 1949 & . & $\ldots$ & 239 & 407 & 202 \\
\hline 1950 & . & . & 174 & 107 & 117 \\
\hline 1951 & $\ldots$ & $\ldots$ & 141 & 497 & 82 \\
\hline 1952 & $\ldots$ & . & 151 & 498 & 106 \\
\hline$\overline{1953}$ & 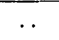 & $\bar{x}$ & 141 & 302 & 85 \\
\hline 1954 & . & . & 101 & 499 & 42 \\
\hline 1955 & $\ldots$ & $\ldots$ & 44 & 52 & 17 \\
\hline
\end{tabular}

by effective methods of treatment and prophylaxis. 
At first the number of infected patients was very large and the repatriation of the first contingents of soldiers caused a great increase of cases on the mainland.

The prophylactic measures which were then made compulsory in the Portuguese army reduced the incidence of venereal disease amongst the soldiers.

marked fall in the incidence of venereal disease within 3 months.

The civilian population presents a different health problem so far as migration is concerned. The danger of venereal infection varies inversely with the social class of the persons involved. There were about 3,000 in Caldas de Raínha from 1941 to 1943 most, of whom were Furopeans of good social standing. The records of the V.D. Dispensary in this town showed no rise in the incidence during this period and there was no hint of the development of clandestine prostitution.

On the other hand, the presence of itinerant labourers, in both town and country, especially when the men are separated from their families, gives rise to social and psychological instability as well as poor sanitary conditions and a certain degree of promiscuity, which is a very important factor in the spread of venereal disease. This, like the movement of troops, leads to the development of clandestine prostitution, and it is therefore necessary to set up V.D. dispensaries in areas where there are periodic migrations of workers, and to make use of the available prophylactic measures.

\section{Conclusions}

1. In Portugal, the increase in V.D. noted in the large towns

The necessity for these drastic steps was clearly proved by the fact that large numbers of the American troops who were stationed at Le Terceira in the Azores in 1957 contracted venereal disease.

Clandestine prostitution which was practically unknown in this area assumed large proportions after the arrival of the American detachment. These women, who numbered about 200, and were extremely active, were probably infected by a few American soldiers from North Africa and they spread both syphilis and gonorrhoea amongst these men at an alarming rate.

The new cases amongst the Portuguese troops on the other hand have been very few and the numbers have remained fairly steady in recent years.

Whereas anti-venereal prophylaxis is compulsory in the Portuguese army it is optional in the American army and only rarely used. The most effective antivenereal precaution was the quick identification of the clandestine consorts, who were given a monthly dose of benzathine penicillin. This step led to a during the second world war was not due to the immigration of foreigners.

2. The movements of the native population assisted the spread of V.D.

3. The increase was governed by the cultural and economic level of the migrants.

4 . When troops are moved anti-venereal prophylaxis should be made compulsory for all soldiers.

5. Soldiers need special surveillance before embarkation and on arrival at a new station, and prostitutes require close supervision with periodical examinations and prophylactic treatment.

\section{Summary}

The conditions which arise when the migration of large numbers of soldiers or civilians favours the spread of V.D. are reviewed.

The part played by troop movements are noted and the need for prophylaxis in combating V.D. is emphasized. In the civil population the social and 
economic status of the migrants and displaced persons is seen to be an important factor.

Measures to check the spread of V.D. are suggested.

Quelques aspects de l'épidémiologie des maladies vénériennes au Portugal pendant la seconde guerre mondiale, 1939-1945

Résumé

L'auteur analyse certaines conditions qui se produisent, quand il y a des mouvements de population et qui favorisent la diffusion des maladies vénériennes dans les pays.

Il se rapporte à l'importance des déplacements des troupes et rehausse la valeur des soins de prophylaxie antivénérienne dans le combat contre ces maladies-là. Au sujet de la population civile, il est d'opinion que le problème est différent selon la catégorie sociale et économique des populations déplacées. À la fin, il propose les mesures à exécuter pour éviter la diffusion des maladies vénériennes. 